\title{
Evaluation of Mechanical Parameters at Compression Test for Different Restorative Composite Resins
}

\author{
ANDRA GAMEN, GIANINA IOVAN, SIMONA STOLERIU, GALINA PANCU, IRINA NICA*, ANDREI GEORGESCU, IONUT TARABOANTA, \\ SORIN ANDRIAN \\ Grigore T. Popa University of Medicine and Pharmacy lasi, Faculty of Dental Medicine,16 Universitatii Str., 700115, Iasi, Romania
}

\begin{abstract}
The purpose of the present study was to evaluate the mechanical parameters at compression tests for two different restorative composite resins. The materials here under study were: Gradia Direct (GC Corporation, Tokyo, Japan) and Filtek Ultimate Universal Restorative, (3M ESPE, St. Paul, MN, USA). 30 cylindrical samples, 15 for each material, with a thickness of $6 \mathrm{~mm}$ and a diameter of $5 \mathrm{~mm}$, were made. The compression behavior atmechanical tests for each sample was analyzed. One-Sample Kolmogorov-Smirnov Test followed by Paired Samples t-Test was used for statistical analysis and determining the level of significance. Gradia Direct had a lower value of Young's modulus than Filtek Ultimate Universal Restorative, the results being statistically significant $(p=0.001<0.05)$. The comparative evaluation of the compressive strength did not reveal statistically significant results between the two materials $(p=0.098>0,05)$. Regarding the compressive strain the values were significantly lower for Filtek Ultimate Universal Restorative $(p=0.000<$ 0.05). The microhybrid composite evaluated in the presentstudy proved to have better mechanical properties than the nanofilled composite.
\end{abstract}

Keywords: mechanical parameters, compression test, restorative composite

In the past few years, composite resins have received many improvements to satisfy the aesthetic requirements of the patients. Their wide use and limitations regarding the mechanical properties have led to numerous researches in order to improve their qualities [1]. Since these materials have to withstand the environmental conditions of the oral cavity and exposure to the masticatory forces, the researches aim to optimize the structure, physical properties and longevity of the composite resins $[2,3]$.

Over time their composition has been modified by increasing filler load. The main types of filler used were glass particles, irregular glass fibers, porous particles and viscosity modifiers [4].

Improvements brought by current research target both resin matrix and inorganic filler $[5,6]$. Regarding the matrix, the development of new monomers is being pursued, and in terms of inorganic filler studies focus on the percentage, size, silanization and development of new particles. The increase of the percentage of inorganic filler by hybridization improves the rigidity, the hardness, the mechanical strength, and it reduces polymerization contraction $[7,8]$.

The decrease of the polymerization shrinkage and improvement of mechanical properties such as traction, compression, or fracture resistance are directly linked to the reduced particle size and their wide distribution [9, 10].

Studies have shown that increasing filler content and particle size reduction improves the qualities of composite resins, especially their strength and wear resistance, so the extremely small particle size (less than $1 \mu \mathrm{m}$ ) should provide optimum physical properties $[11,12]$.

The mechanical properties of dental materials are usually evaluated using compression testing. The assessment of restorative materials resistance under such conditions is very important because most of the masticatory forces are part of the compressive force category [13-15].
The purpose of the present study was to evaluate the mechanical parameters at compression tests for two different restorative composite resins, a nanofilled and a microhybrid one.

\section{Experimental part}

Two different restorative materials were studied: Filtek Ultimate Universal Restorative (3M ESPE, St. Paul, MN, USA) and Gradia Direct (GC Corporation, Tokyo, J apan).

Filtek Ultimate Universal Restorative (3M ESPE), is a nanofilled composite, activated in visible light. The material is indicated for direct restoration of both anterior and posterior teeth. The organic matrix consists of a mixture of bis-GMA, UDMA, TEGDMA and bis-EMA. The fillers are represented by nanometric silica particles, nanometric zirconia particles and clusters of silica and zirconia particles having micrometric dimensions. The loading with inorganic filler is about $78.5 \%$ by weight respectively $63.3 \%$ by volume.

Gradia Direct (GC CORPORATION) is a microhybrid composite used for restoration to anterior and posterior teeth. The organic matrix is represented by UDMA (urethane dimetacrylate) and the inorganic matrix of a mixture of silicate and polymerized filler. The filler content is loaded to $65 \%$ by volume and $77 \%$ by weigh and the average particle-size diameter is $0.85 \mu \mathrm{m}$.

The characteristics of composite materials tested in the study are presented in Table 1.

For this study, 30 cylindrical samples were made, 15 for each material. The composite resins were placed in plastic conformers having the height of $6 \mathrm{~mm}$ and the diameter of $5 \mathrm{~mm}$, in accordance to ISO standards 4049 and ANSI/ ADA No. 27. All the samples were manufactured using the stratification technique ( 3 layers of $2 \mathrm{~mm}$ thickness). A LED lamp (COXO, Latte) having the wavelength between $440 \mathrm{~nm}$ and $480 \mathrm{~nm}$ was used for light curing each layer for 40s. A glass slide and a mylar strip were used for removing the excess material during sample preparation and for getting a surface without air voids. 
Table 1

CHARACTERISTICS OF TESTED MATERIALS

\begin{tabular}{|c|c|c|c|c|c|}
\hline \multirow{3}{*}{$\begin{array}{c}\text { Material/Manufactur } \\
\text { er }\end{array}$} & \multirow{3}{*}{$\begin{array}{c}\text { Type/ } \\
\text { Batch No./Shade }\end{array}$} & \multicolumn{4}{|c|}{ Chemical composition } \\
\hline & & \multirow{2}{*}{ Matrix } & \multicolumn{3}{|c|}{ Filler } \\
\hline & & & Type & Size & Load \\
\hline \multirow{3}{*}{$\begin{array}{c}\text { Filtek Ultimate } \\
\text { Universal } \\
\text { Restorative/3M ESPE, } \\
\text { St.Paul, MN, USA }\end{array}$} & \multirow{3}{*}{$\begin{array}{c}\text { Nanofill/ N615433/Enamel } \\
\text { A3 }\end{array}$} & bis-GMA, & Silica particles & $20 \mathrm{~nm}$ & \multirow{3}{*}{$\begin{array}{l}78.5 \text { wt } \% \\
63.3 \text { vol } \%\end{array}$} \\
\hline & & \multirow{2}{*}{$\begin{array}{l}\text { UDMA, } \\
\text { TEGDMA, } \\
\text { bis-EMA (6) }\end{array}$} & Zirconia particles & $\begin{array}{c}4-11 \\
\mathrm{~nm}\end{array}$ & \\
\hline & & & $\begin{array}{l}\text { Clusters of silica } \\
\text { and zirconia } \\
\text { particles }\end{array}$ & $\begin{array}{c}0.6-10 \\
\mu \mathrm{m}\end{array}$ & \\
\hline $\begin{array}{c}\text { Gradia Direct/ } \\
\text { GC } \\
\text { CORPORATION,Tok } \\
\text { yo, Japan }\end{array}$ & Microhybrid/N1809262/P-A2 & $\begin{array}{c}\text { UDMA } \\
\text { Other } \\
\text { methacrylates (not } \\
\text { specified) }\end{array}$ & $\begin{array}{l}\text { Silica/ } \\
\text { polymerized } \\
\text { particles }\end{array}$ & $0,85 \mu \mathrm{m}$ & $\begin{array}{l}77 \text { wt } \% / \\
65 \text { vol } \%\end{array}$ \\
\hline
\end{tabular}

Bis-GMA: Bisphenol A diglycidyl ether dimethacrylate; UDMA: urethane dimethacrylate,

TEGDMA:Triethyleneglycoldimethacrylate;bis-EMA(6): ethoxylated bisphenol-A dimethacrylate.

The quantitative analysis of the compression behavior was done immediately after the samples were made. We used the servo hydraulic INSTRON 3382 (Norwood, MA, USA) test equipment, having the technical specifications: $100 \mathrm{kN}$ maximum load, testing speed between $0.005 \mathrm{~mm} /$ min and $500 \mathrm{~mm} / \mathrm{min}$, the maximum force of $50 \mathrm{kN}$ for the maximum speed and the maximum speed of $250 \mathrm{~mm} /$ min for the maximum speed. To record the data and subsequent calculations, the Bluehill ${ }^{\circledR}$ Lite software was used. For the present measurements, we used the compression test in axial direction of the samples, atroom temperature and $0.5 \mathrm{~mm} / \mathrm{min}$ speed, which was preserved constant during the experiments. In order to characterize the behavior of composite resins at the compression test, we recorded for each sample, the characteristic curves, consisting in dependencies between the applied forces $(\mathrm{N})$ and absolute deformations $(\mathrm{mm})$. They show the features of each tested material, and also allow calculating specific parameters. First, by taking into account the initial geometrical sizes (diameters and lengths), the dependences between stress [Pa] and strain [\%] were obtained. Then, using these curves, the following mechanical parameters were derived: ultimate compressive strength [MPa], ultimate compressive strain [\%], and compression Young's Modulus. Finally, the normality test (Kolmogorov-Smirnov) was applied to observe data distribution, while for comparing the data groups the Paired Samples t-Test was employed.

\section{Results and discussions}

In figure 1 the stress-strain dependences for the samples of Filtek Ultimate Universal Restorative composite resin are plotted. For this material, in comparison with Gradia Direct, almost similar compressive strength values resulted, but the ultimate compressive strain was lower. By averaging, the maximum force applied for samples breaking was $4314 \mathrm{~N}$, while the ultimate stress was obtained between $170 \mathrm{MPa}$ and $290 \mathrm{MPa}$. A distinct behavior was obtained for Sample no. 6 that was rapidly broken (for a force of $1827 \mathrm{~N}$ ), in our opinion due to some defects of its microstructure (initial micrometric holes). For samples no. 4 and 11, the stress-strain linear dependence was not obtained, and consequently the mechanical parameters were not calculated. Even in these circumstances, our data provided significant information regarding to the general compression behavior: the curves aspectindicates a brittle fracture, without a region of plasticity. In the stress range of 150-250 (MPa) a jagged appearance of most of these

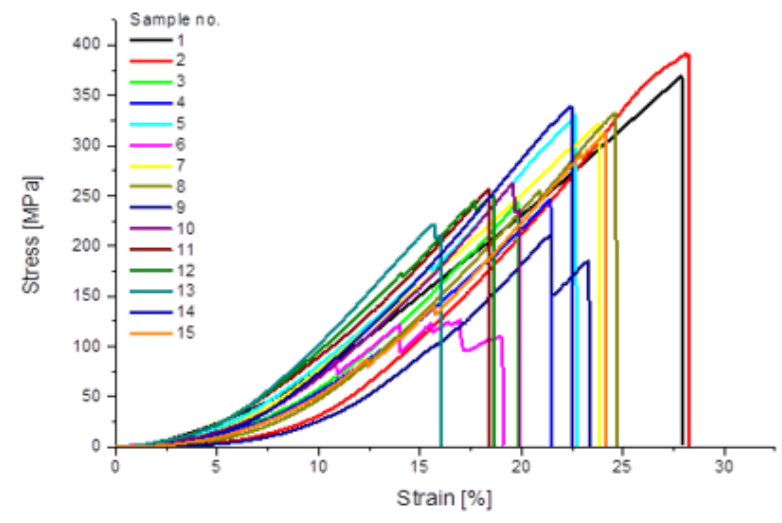

Fig. 1. The stress-strain compressive curves for Filtek Ultimate Universal Restorative

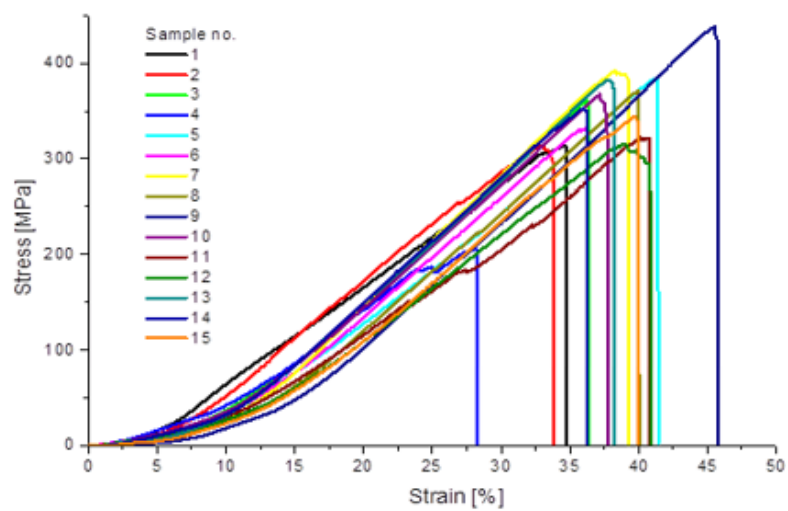

Fig. 2. The stress-strain compressive curves for Gradia Direct

dependencies can be noticed, which can be given by some micro-cracks that propagate through the samples up to their final break.

In Figure 2 are represented the compressive stress-strain curves for Gradia Direct, similar as above, in the form of stress-strain dependences. Generally, between $200 \mathrm{MPa}$ and $300 \mathrm{MPa}$, we recorded linear dependences that permitted calculating the compression Young's modulus (E) for all 15 samples. The average force applied up to breakage had a value of $4216 \mathrm{~N}$. Again, an exception was observed for Sample No. 4 having a low ultimate stress, possibly due to some initial structural defects.

To make a comparison between the mechanical parameters obtained for both studied composites, in Table 2 are presented the average values and the standard deviations. 


\begin{tabular}{|c|c|c|c|}
\hline Material & $\begin{array}{c}\text { Compression Young's } \\
\text { modulus, } E(\mathrm{MPa})\end{array}$ & $\begin{array}{c}\text { Ultimate compressive } \\
\text { strength }(\mathrm{MPa})\end{array}$ & Ultimate compressive strain (\%) \\
\hline Filtek Ultimate & $1144.007 \pm 229.457$ & $223.584 \pm 49.427$ & $24.716 \pm 4.362$ \\
\hline Gradia Direct & $863.803 \pm 144.664$ & $250.723 \pm 32.923$ & $37.968 \pm 4.045$ \\
\hline
\end{tabular}

Table 2

Table 3

PAIRED SAMPLES T-TEST RESULT FOR YOUNG'S MODULUS

\begin{tabular}{|c|c|c|c|c|c|c|c|c|}
\hline \multirow{3}{*}{ Pair } & \multicolumn{5}{|c|}{ Paired Differences } & \multirow{3}{*}{$\mathrm{t}$} & \multirow{3}{*}{ df } & \multirow{3}{*}{ Sig.(2-tailed) } \\
\hline & \multirow{2}{*}{ Mean } & \multirow{2}{*}{ Std.Deviation } & \multirow{2}{*}{$\begin{array}{l}\text { Std. Error } \\
\text { Mean }\end{array}$} & \multicolumn{2}{|c|}{$\begin{array}{l}95 \% \text { Confidence Interval of } \\
\text { the Difference }\end{array}$} & & & \\
\hline & & & & Lower & Upper & & & \\
\hline $\begin{array}{l}\text { Young's 'sodulus for } \\
\text { Compression for Filtek } \\
\text { Ultimate - Young's Modulus } \\
\text { for Compreasion for Gradia } \\
\text { Direct }\end{array}$ & 280.20440 & 254.99974 & 65.84065 & 138.99025 & 421.41855 & 4.256 & 14 & .001 \\
\hline
\end{tabular}

Table 4

PAIRED SAMPLES T-TEST RESULT FOR ULTIMATE COMPRESSIVE STRENGHT

\begin{tabular}{|c|c|c|c|c|c|c|c|c|}
\hline \multirow{3}{*}{ Pair } & \multicolumn{5}{|c|}{ Paired Differences } & \multirow{3}{*}{$t$} & \multirow{3}{*}{ df } & \multirow{3}{*}{ Sig.(2-tailed) } \\
\hline & \multirow{2}{*}{ Mean } & \multirow{2}{*}{ Std.Deviation } & \multirow{2}{*}{$\begin{array}{l}\text { Std Error } \\
\text { Mean }\end{array}$} & \multicolumn{2}{|c|}{$\begin{array}{l}95 \% \text { Confidence Interval of } \\
\text { the Difference }\end{array}$} & & & \\
\hline & & & & Lower & Upper & & & \\
\hline $\begin{array}{l}\text { Ultimate Compressive } \\
\text { Strenght for Filtek Ultimate - } \\
\text { Ultimate Compressive } \\
\text { Strenght for Gradia Direct }\end{array}$ & -27.13927 & 59.21590 & 15.28948 & -59.93194 & 5.65340 & -1.775 & 14 & .098 \\
\hline
\end{tabular}

The results obtained after subjecting the two materials to compression tests were compared using Paired Samples t-Test.

Regarding the Young's Modulus, it was observed that its value was significantly higher for Filtek Ultimate than for Gradia Direct, t $\mathrm{t}$ (14) $=4.25$ and $p=0.001<0.05$ (Table 3).

For compressive strength, Paired Samples t-Test indicated no relevant differences between the two composites when comparing the values for this parameter, $\mathrm{t}(14)=-1.775$ and $p=0.098>0.05$ (Table 4).

When comparing the results for compressive strain, it was observed that there are relevant differences between the two composite resins, $t(14)=-8.054$ and $p=0.000<$ 0.05 (Table 5).

In the present study, experimental measurements of mechanical parameters were obtained using universal equipment. The compression tests revealed specific features of each restorative composite. Thus, for Gradia Direct we obtained a low average value for the Young's modulus, $(E=863.803 \mathrm{MPa}$ ) and we concluded a high deformability of this material. This is also in agreement with the high ultimate strain of $37.968 \%$, at which areas of slight plastic deformations were detected. Similar aspects have been highlighted in other studies [16, 17].

Regarding to Filtek Ultimate composite, the higher mean value of elasticity modulus, correlated with the lower mean value for compressive strain, proved that this material is quite rigid (less deformable), being broken abruptly. This is in line with the principle that, applying the same force, when the $E$ value tends to increase the samples deformation tends to decrease [18].

This feature was also reported by various authors, concluding that the mechanical properties of Filtek Ultimate are lower when comparing with other micro-hybrid composites $[19,20]$. Both composite materials had almost similar mean values of compressive strength (Table 2), which may be a consequence of high filler load (Table 1). Various works had concluded that the ultimate compressive strength is influenced by many factors, such as the composition of the organic matrix, the type and amount of filler load and the bulk fraction of the reinforcement elements [21-24].

The general shape of the strain-stress characteristic curves of the both investigated materials indicates a typical fragile behavior, without almost any plastic deformation before fracture. This agrees with the conclusions from other research, where all the composites broke at the stress corresponding to the elastic limit of the material [25-27].

Having in view that for both the investigated composite materials the filler load and chemical composition are almost similar, the differences between the behavior at the compression tests can be given in our opinion by the inorganic particle distribution. Thus, for Filtek Ultimate Universal Restorative the nanoparticle agglomeration

Table 5

PAIRED SAMPLES T-TEST RESULT FOR ULTIMATE COMPRESSIVE STRAIN

\begin{tabular}{|c|c|c|c|c|c|c|c|c|}
\hline \multirow{3}{*}{ Pair } & \multicolumn{5}{|c|}{ Paired Differences } & \multirow{3}{*}{$\mathrm{t}$} & \multirow{3}{*}{ df } & \multirow{3}{*}{ Sig-(2-tailed) } \\
\hline & \multirow{2}{*}{ Mean } & \multirow{2}{*}{ Std.Deviation } & \multirow{2}{*}{$\begin{array}{l}\text { Std Error } \\
\text { Mean }\end{array}$} & \multicolumn{2}{|c|}{$\begin{array}{l}95 \% \text { Confidence Interval of } \\
\text { the Difference }\end{array}$} & & & \\
\hline & & & & Lower & Upper & & & \\
\hline $\begin{array}{l}\text { Ultimate Compressive Strain } \\
\text { for Filtek Ultimate - Ultimate } \\
\text { Compressive Strain for Gradia } \\
\text { Direct }\end{array}$ & -13.25200 & 6.37276 & 1.64544 & -16.78112 & -9.72288 & -8.054 & 14 & .000 \\
\hline
\end{tabular}


determines the presence of nanoclusters, and correspondingly the existence of a different breaking mechanism, when comparing with spherical or irregular particles of micrometric sizes [28-30]. Our findings are in agreement with other studies which revealed that the nanoclusters tend to render the material stiffer and increase the Young's modulus mean values when compared to the composite resins with irregular micrometric ûllers [31-33]. Nanoclusters tend to increase the material resistance to external forces through crack reflection leading to increased fatigue tolerance [34-36]. And yet our results show ed that there wasn't significant difference between the mean values of compressive strength when comparing the nanofilled composite to the hybrid one. Gradia Direct is a hybrid composite whose inorganic load contains silica and polymerized particles (Table 1). Some authors stated that pre-polymerized particles have the potential to improve machanical properties of the material [37-40]. This could be an explanation of the very close values of compressive strength for the two tested materials. Although the data indicated in the literature for compressive strength widely varies, it is accepted that the mechanical properties of hybrid composite remain comparable to the ones of nanocomposite [41-44]. Regarding the compressive strain, a significant higher value was observed for Gradia Direct. A possible explanation of these properties lies in the different crack propagation mechanism during deformation. Thus, it can be appreciated that the micrometric particles of Gradia Direct block crack propagation and reflection, while nanometric particles from Filtek Ultimate allow it. In fact, the curves in Figure 1 and 2, indicate a stronger cracking of Filtek Ultimate than Gradia Direct before breaking.

Even with these differences, both analyzed composite materials are a suitable choice for direct restorations on the lateral teeth.

\section{Conclusions}

Our experimental measurements showed that Filtek Ultimate has a higher value of compressive Young's modulus and a lower one of ultimate compressive strain when compared to Gradia Direct. No relevant differences were obtained between the values of ultimate compressive strength. The compressive stress-strain curves indicated a brittle fracture of both materials, more pronounced in the case of Filtek Ultimate which revealed small plastic deformations before its breaking.The microhybrid composite evaluated in the present study proved to have better mechanical properties than the nanofill one.

\section{References}

1.RAKHEE, R., JAYASREE, S., RAMESH, K., PRASHANT, B., RAJEESH, M.K., ABDU SEMEER, P., IOSR-J DMS, 16, no. 12, 2017, p. 65.

2.PAPADOGIANNIS, Y., LAKES, R.S., PALAGHIAS, G., HELVATJOGLUANTONIADES, M., PAPADOGIANNIS, D., Dent. Mater., 23, no. 3, 2007, p. 235.

3.GRADINARU, I., IGNAT, L., DASCALU, C.G., SOROGA, L.V., ANTOHE, M.E., Rev. Chim. (Bucharest), 69, no. 3, 2018, p. 328.

4.LEEVAILOJ, C., COCHRAN, M.A., MATIS, B.A., MOORE, B.K., PLATT, J.A., Oper. Dent., 26, no.3, 2001, p. 302.

5. LIEN, W., WANDEWALLE, K.S., Dent. Mater., 26, no. 4, 2010, p. 337. 6. BEUN, S., GLORIEUX, T., DEVAUX, J., VREVEN, J., LELOUP, G., Dent. Mater., 23, no. 1, 2007, p. 51.

7.BLACKHAM, J.T., VANDEWALLE, K.S., LIEN, W., Oper. Dent., 34, no. 6, 2009, p. 697

8. BALAN, A., ANDRIAN, S., SAVIN, C., SANDU, A.V., PETCU, A., STOLERIU, S., Rev. Chim. (Bucharest), 66, no. 4, 2015, p. 562. 9.TAKESHIGE, F., KAWAKAMI, Y., HAYASHI, M., EBISU, S., Dent. Mater., 23, no. 7, 2007, p. 893.
10.GRADINARU, I., NICA, I., ANTOHE, M.E., Romanian J ournal of Oral Rehabilitation, 9, no. 3, 2017, p. 62

11.IOVAN, G., STOLERIU, S., PANCU, G., TOPOLICEANU, C., CIOBANU, M.C., ANDRIAN, S., Romanian Journal of Oral Rehabilitation, 6, no. 2, 2014, p. 18.

12.KIM, K.H., ONG, J.L., OKUNO O., J. Prosthet. Dent., 87, no. 6, 2002, p. 642.

13.SABATINI, C., CAMPILLO, M., HOELZ, S., DAVIS, E.L., MUNOZ, C.A., Oper. Dent., 37, no. 1, 2012, p. 37.

14.SATTERTHWAITE, J.D., MAISURIA, A., VOGEL, K., WATTS, D.C., Dent. Mater. J., 28, no. 6, 2012, p. 609.

15.NICA, I., CIMPOIESU, N., RUSU, V., ANDRONACHE, M., STEFANESCU, C., Mat. Plast., 49, no. 2, 2012, p. 176.

16.EL-SAFTY, S., SILIKAS, N., WATTS, D.C., Dent. Mater., 28, no. 8, 2012, p. 928.

17.BAYNE, S.C., Dent. Mater., 28, no. 1, 2012, p. 52.

18.SATTERTHWAITE, W.D., VIGEL, K., WATTS, D.C., Dent. Mater. J ., 25, no.12, 2009, p. 1612.

19.HAMBIRE, U.V., TRIPATHI, V.K., MAPARI, A.G., ARPN J. Eng. Appl. Scie., 7, no. 8, 2012, p. 1066.

20.MOSZNER, N., KLAPDOHR, S., Int. J. Nanotechnol., 1, no. 1-2, 2004, p.130.

21.NICA, I., IOVAN, G., STOLERIU, S., GHIORGHE, C.A., PANCU, G., COMANECI, R., ANDRIAN, S., Mat. Plast., 55, no. 3, 2018, p. 447.

22.THOMAIDIS, S., KAKABOURA, A., MUELLER, W.D., ZINELIS, S., Dent. Mater., 29, no. 8, 2013, p. 132.

23.ORNAGHI, B.P., MEIER, M.M., LOHBAUER, U., BRAGA, R.R., Dent. Mater., 30, no. 7, 2014, p. 742.

24.IVANISEVIC, A., LAINOVIC. T., VILOTIC, D., BLAZIC. L., GERIC. K., VILOTIC. M., Journal for Technology of Plasticity, 38, no. 1, 2013, p. 23.

25.SIDERIDOU, I.D., KARABELA, M.M., VOUVOUDI, E.C.H., Dent. Mater., 27, no. 6, 2011, p. 598.

26.MEENAKUMARI, C., BHAT, K.M., BANSAL, R., SINGH, N., Contemp. Clin. Dent., 9, Suppl.1, 2018, p. S142.

27.LEPRINCE, J.G., PALIN, W.M., VANECKER, J , SABBAGH, J ., DEVAUX, J., LELOUP, G., J. Dent., 42, no.8, 2014, p. 993.

28.ALZRAIKAT, H., BURROW, M.F., MAGHAIREH, G.A., TAHA, N.A., Oper.Dent., 43, no. 4, 2018, p. E173.

29.HAHNEL, S., HENRICH, A., BÜRGERS, R., HANDEL, G., ROSENTRITT, M., Oper. Dent., 35, no. 4, 2010, p. 412.

30.TOFAN, N., ANDRIAN, S., NICA, I., STOLERIU, S., TOPOLICEANU, C., CHELARIU, R., BOLAT, M., PANCU, G., Rev. Chim. (Bucharest), 67, no. 6, 2016, p. 1144.

31.MASOURAS, K., AKHTAR, R., WATTS, D.C., SILIKAS, N., J. Mater. Sci. Mater. Med., 19, no. 12, 2008, p. 3561.

32.CAMPODONICO, C.E., TANTBIROJN, D., OLIN, P.S., VERSLUIS, A., J. Am. Dent. Assoc., 142, no. 10, 2011, p. 1176.

33.STOLERIU, S., ANDRIAN, S., NICA, I., SANDU, A.V., PANCU, G., MURARIU, A., IOVAN, G., Mat. Plast., 54, no. 3, 2017, p. 574.

34.RUDDELL, D.E., MALONEY, M.M., THOMPSON, J.Y., Dent. Mater., 18, no. 1, 2002, p. 72.

35.TURSSI, C.P., FERRACANE, J.L., VOGEL, K., Biomaterials, 26, no. 24, 2005, p. 4932

36.GHIORGHE, C.A., IOVAN, G., TOPOLICEANU, C., SANDU, A.V., ANDRIAN, S., Rev. Chim. (Bucharest), 64, no. 12, 2013, p. 1436.

37.CZASCH P., ILIE N., Clin. Oral Invest., 17, no.1, 2013, p. 227.

38.LOHBAUER, U., BELLI, R., FERRACANE, J.L., J. Dent. Res., 92, no.7, 2013, p. 584.

39.ANDRIAN, S., PANCU, G., TOPOLICEANU, C., TOFAN, N., STOLERIU, S., IOVAN, G., Rev. Chim. (Bucharest), 68, no. 8, 2017, p. 1874. 40.MOEZZYZADEH, M., Journal Dental School, 1, 2012 p. 24.

41.GHIORGHE, C.A., TOPOLICEANU, C., ANDRIAN, S., CARLESCU, V., PANCU, G., GAMEN, A.C., NICA, I., IOVAN, G., Romanian Journal of Oral Rehabilitation, 10, no.2, 2018, p. 38.

42.PEUTZFELDT, A., ASMUSSEN, E., J. Dent., 28, no. 6, 2000, p. 447. 43.GAVRILA, L., BALAN, A., MURARIU, A., SANDU, A.V., SAVIN, C., Rev. Chim. (Bucharest), 67, no. 11, 2016, p. 2228.

44.AGRAWAL, A., MALA, K., J. Conserv. Dent., 17, no.3, 2014, p. 230.

Manuscript received: 17.06 .2019 